\title{
Isusova ostavljenost na križu i kršćansko razumijevanje Boga kao trojstvenoga zajedništva
}

Egzegetska analiza i trinitarno-teološko promišljanje Mk 15,34 i Mt 27,46 kroz teologiju Jürgena Moltmanna i Hansa Ursa von Balthasara

Marija Pehar*, Vjeran Lazici***

\begin{abstract}
Sažetak
Isusova objava Boga kao trojstvenoga zajedništva u ovom je radu promišljana polazeći od njegove osamljenosti i razdvojenosti od Oca u trenutku smrti na križu, izražene vapajem »Bože moj, Bože moj, zašto si me ostavio? « (Mk 15,34; Mt 27,46). Prvi dio rada donosi kritičku egzegezu navedenih redaka u grčkom izvorniku, te istovremeno kao opravdano otvara pitanje može li se stvarna Isusova napuštenost od nebeskoga Oca razumjeti i kao bitna kritika kršćanskoga nauka o Bogu kao neraskidivom zajedništvu ljubavi. Stoga su u drugom dijelu dobiveni egzegetski rezultati uspoređeni s kršćanskim trinitarnim naukom, i to kroz prikaz trinitarno-teoloških doprinosa Moltmanna i Balthasara. U trećem se dijelu kroz pneumatološku dimenziju i soteriološko usmjerenje trinitarnoga nauka ukazuje na istinski trinitarno-teološki potencijal Isusove realne osamljenosti u smrti na križu i mogućnost novoga tumačenja Boga kao ljubavi.
\end{abstract}

Ključne riječi: Isusova ostavljenost; Trojstvo; Jürgen Moltmann; Hans Urs von Balthasar

\section{Uvod}

Kršćanski trinitarni nauk temeljni je sadržaj kršćanske vjere, a time i temeljno određenje kršćanske teologije. Riječ je o sadržaju koji svojom racionalnom težinom, povijesnom jedinstvenošću, ali i sadržajnom paradoksalnošću, trajno uznemiruje i proziva kršćansku teologiju te ju poziva na uvijek novo promišljanje

* Izv. prof. dr. sc. Marija Pehar, Katolički bogoslovni fakultet Sveučilišta u Zagrebu. Adresa: Vlaška 38, 10000 Zagreb, Hrvatska. ORCID iD: https://orcid.org/0000-0002-8083-1896.

E-adresa:m.marijape@gmail.com

* Vjeran Lazić, doktorand, Filozofski fakultet Sveučilišta u Zagrebu. Adresa: Ivana Lučića 3, 1000 Zagreb, Hrvatska. ORCID iD: https://orcid.org/0000-0003-3783-0801. E-adresa: vjeran.09@gmail.com 
i dublje razumijevanje. Ona se pritom razumije prije svega kao izlaganje biblijske objave, odnosno Božje samoobjave po Isusu Kristu. Upravo po njemu, kao konačnoj Božjoj objavi, Božji se bitak pokazuje kao trojstveno zajedništvo ljubavi, a ta se objava Boga očituje i kao objava Božje djelotvorne spasenjske volje za čovjeka.

Ipak, uz brojna novozavjetna mjesta koja upućuju na objavu Božjega bića kao zajedništva savršene ljubavi, uvijek iznova zbunjuje jedno mjesto za koje se čini da to zajedništvo ljubavi dovodi u pitanje i u potpunoj kontradiktornosti upućuje na pitanje stvarnih unutartrojstvenih odnosa. Riječ je o Isusovu vapaju s križa u trenutku umiranja. Redak »Bože moj, Bože moj, zašto si me ostavio? «, zabilježen u Markovu $(27,46)$ i Matejevu $(15,34)$ evanđelju, otvara se tako ne samo kao iskaz unutarnje boli umirućega Isusa, nego se može razumjeti i kao najozbiljnija kritika kršćanskoga nauka o Bogu kao zajedništvu ljubavi. Postavlja se pitanje: Je li taj Isusov vapaj s križa potvrda njegove stvarne ostavljenosti od Oca? Ako jest, može li se tada shvatiti kao negacija Božjega unutartrojstvenoga zajedništva kao zajedništva neraskidive ljubavi? Nije li taj vrhunac objave, dakle najveće razotkrivanje Boga, u isto vrijeme i najveća kritika kršćanskoga Boga? S tim u vezi postavlja se nužno i soteriološko pitanje: Što od takvoga Boga koji je svojega Sina ostavio, može očekivati čovjek? Je li Božja ljubav prema čovjeku kategorija ograničene i uvjetovane vrijednosti?

Iako su takva pitanja u teološkim promišljanjima već postavljana, u ovom im se radu pristupa na način izravnoga suočavanja Isusova vapaja s križa s iznesenim temeljnim teološkim sadržajem kršćanskoga nauka i trinitarne teologije. Stoga je u prvom dijelu najprije provedena kritička egzegeza navedenoga evanđeoskoga retka u grčkom izvorniku, s ciljem otkrivanja njegova književno-literarnoga značenja i propitivanja njegova trinitarno-teološkoga potencijala. U drugom su dijelu, u usporedbi s dobivenim egzgetskim rezultatima, izložena i analizirana dva pokušaja novije trinitarne teologije, s ciljem da kroz njih bude izloženo ispravno usuglašavanje Isusova krika i teološke refleksije o Božjem unutartrojstvenom biću. Sa željom da izbjegnemo konfesionalne uvjetovanosti i naglasimo jedinstven kršćanski sadržaj te teološke problematike, iznosimo trinitarno-teološke doprinose evangeličkoga teologa Jürgena Moltmanna i katoličkoga teologa Hansa Ursa von Balthasara. Na kraju, otvarajući pneumatološku dimenziju i soteriološko usmjerenje kršćanskoga trinitarnoga nauka, onako kako su to učinili i Moltmann i Balthasar, u trećem dijelu pokušavamo pronaći odgovor na postavljena pitanja i uputiti na njihovu antropološku relevantnost.

\section{1. »Bože moj, Bože moj, zašto si me ostavio?«(Mk 15,34; Mt 27,46) kao trinitarni iskaz Novoga zavjeta}

Kristološko-trinitarni nauk kao temeljni sadržaj kršćanske vjere proizlazi iz iskustva vjere u Isusa Krista, odnosno novozavjetnih odgovora o pitanju spasenja. Iz događaja Božje samoobjave u Isusu Kristu otkriva nam se Bog kao zajedništvo ljubavi Oca, Sina i Duha Svetoga, te se to Božje samoočitovanje može 
sažeti u rečenicu »Bog je ljubav«(1 Iv 4,8.16; Müller, 2005, 415-476). Međutim, $\mathrm{u}$ istoj novozavjetnoj objavi postoje mjesta koja istina potvrđuju trinitarnu strukturu samoga događaja objave i njegovu trinitarnu eksplikaciju, ali kao da dovode u pitanje sukladnost nekih iskustava Isusova života s navedenim određenjem Boga kao ljubavi. Jedno takvo teško mjesto svakako je Isusov vapaj s križa: »Bože moj, Bože moj, zašto si me ostavio? «(Mk 15,34; Mt 27,46). Želimo ga promotriti najprije kroz egzegetsku analizu izvornoga grčkoga teksta.

\subsection{Kontekst i egzegetska analiza Mk 15,34 i Mt 27,46}

Jedan je od pristupa tumačenju muke analiza Isusovih riječi s križa, koje su redovito tumačene $\mathrm{u}$ kontekstu redakcije i teologije svakoga pojedinoga evanđelja. ${ }^{1}$ Tako od sedam posljednjih Kristovih izjava jedna je kod Marka i Mateja, tri kod Luke i tri kod Ivana. Ovdje se zaustavljamo na tumačenju riječi koje donose Marko u 15,34 i Matej u 27,46: »Bože moj, Bože moj, zašto si me ostavio?«, čiju važnost evanđelisti naglašavaju transkripcijom izvornika (Zovkić, 1983, 197198). Te retke analiziramo stavljajući naglasak na razlike u pisanju i tumačenju u sklopu navedenih evanđelja (Fabris, 1996, 570-573; Focant, 2015, 616-620).

\subsection{Egzegeza teksta}

U Isusovu vapaju s križa u Matejevu i Markovu evanđelju može se primijetiti da je on vjerna kopija psalamskoga retka Ps 22,2. Radi boljega razumijevanja razlike i značenja, navest ćemo taj redak iz Septuaginte (Ps 21,2) ${ }^{2}$, te Isusov vapaj u grčkom tekstu Matejeva i Markova evanđelja uključujući grčku transkripciju i prijevod Isusova uzvika prema izdanju Eberharda Nestlea i Kurta Alanda (1986).

Tablica 1. Usporedni prikaz Ps 21,2 (LXX) s Mt 27,46 i Mk 15,34

Table 1. Comparative presentation Ps. 21:2 (LXX) with Mt. 27:46 and Mk. 15:34

\begin{tabular}{|c|c|c|}
\hline $\begin{array}{c}\text { Mjesto u Svetom } \\
\text { pismu }\end{array}$ & Tekst Svetoga pisma & Nestle i Aland, 1986. \\
\hline Ps 21,2 (LXX) & 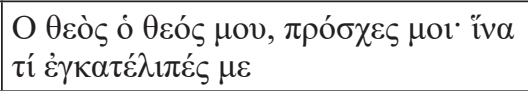 & \\
\hline $\begin{array}{l}\text { Mt } 27,46 \\
\text { (Nestle i Aland, } \\
\text { 1986) }\end{array}$ & 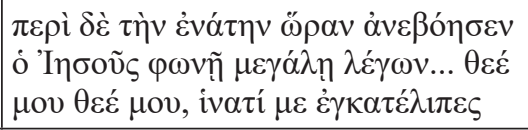 & 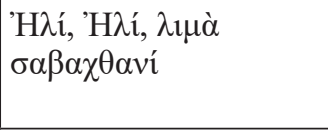 \\
\hline $\begin{array}{l}\text { Mk 15,34 } \\
\text { (Nestle i Aland, } \\
\text { 1986) }\end{array}$ & 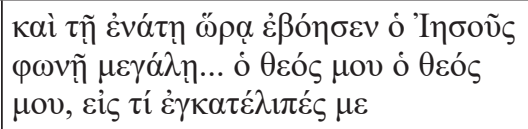 & 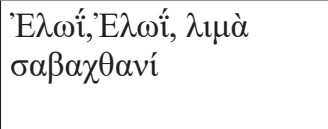 \\
\hline
\end{tabular}

1 Za uvid u širi kontekst Evanđelja u kojem su smješteni analizirani redci usp. Popović, 2009, 20; Brown, 2008, 136-146.

2 Riječ je o različitom načinu brojenja psalama u grčkoj i hebrejskoj varijanti. 


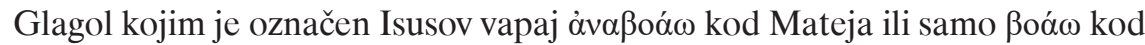
Marka stavljen je u aktivni aorist, vrijeme koje označava svršenu radnju koja se dogodila u prošlosti, a znači "vikati, povikati, zavapiti”. Takav oblik glagola s prefiksom jedino se koristi na tom mjestu u Novom zavjetu, a bez prefiksa korišten je 12 puta u svim novozavjetnim tekstovima, od čega dva puta kod Marka i jednom kod Mateja (Popović, 2016, 22 i 43). U Starom zavjetu njegov hebrejski je pandan korišten za opis vapaja ugroženih koji traže Božju pomoć (usp. Izl 14,10; Pnz 26,7; Jdt 5,12) zbog velike tjeskobe i snažne tjelesne patnje (Popović,

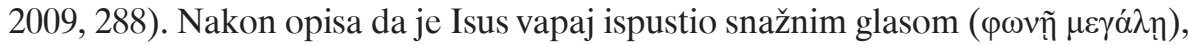
dobro je uočiti kako se Matej koristi izrazom $\lambda \dot{\varepsilon} \gamma \omega v$, koji je particip prezenta aktivnoga glagola $\lambda \dot{\varepsilon} \gamma \omega$ ("govoriti”). Time on naznačuje kako prepričava Isusove riječi s križa, a Marko stavlja čitatelja u izravan odnos slušanja onoga što dolazi izostavljajući taj particip: "govoreći”.

Egzegeti se slažu kako navođenjem Isusova vapaja na aramejskom jeziku s grčkom transkripcijom Marko i Matej žele naglasiti njegovu povijesnost (Lane, 1974, 127). Razlika je u imenovanju adresata vapaja. Marko se koristi riječju 'E $\lambda \omega \hat{i}$, a Matej 'H $\lambda$ í. Stariji autori pitaju se je li originalan izraz bio na aramejskom (prema Marku) ili na hebrejskom (prema Mateju), te se neki odlučuju za drugu opciju zbog pomišljanja Židova da Isus zove Iliju (Brather i Nida, 1961, 491). Matej tu stvara svojevrsnu mješavinu hebrejske i aramejske formule, kako bi, po svemu sudeći, izbjegao mogućnost poistovjećivanja Isusova Oca s Ilijom (Gnilka, 1988, 475). ${ }^{3}$ Vjerojatnija je aramejska verzija kako ju navodi Marko, jer to je rečenica koju posljednju izgovara čovjek Isus Bogu na svojem materinskom jeziku.

U prijevodu na grčki Matej se služi vokativom u Isusovu zazivu Boga ( $\theta \varepsilon \varepsilon$ $\mu \mathrm{ov),} \mathrm{što} \mathrm{je} \mathrm{jedino} \mathrm{mjesto} \mathrm{u} \mathrm{kojem} \mathrm{se} \mathrm{Isus} \mathrm{Bogu} \mathrm{ne} \mathrm{obraća} \mathrm{riječju} \mathrm{"Oče"} \mathrm{u} \mathrm{tom}$ evanđelju (France, 1987, 407), a Marko aramejske riječi zaziva izjednačava s grčkim nominativom ( $\theta \varepsilon o ́ \varsigma \mu$ ov), što je česta pojava u novozavjetnim tekstovima (usp. Lk 18,11.13; Iv 20,28; Heb 1,8; 10,7) (Popović, 2009, 289). Ta dva teksta

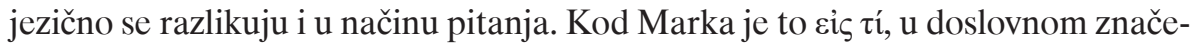
nju “zbog čega?, po čemu?" (Popović, 2009, 292; Popović, 2016, 61), a kod Mateja ivatí, što se prevodi “zašto?, zašto da?, s kojom nakanom?” (Popović 2016, 92). U odnosu na tekst iz Septuaginte, oslovljavanje Boga u nominativu istovjetno je Markovu, a oblik pitanja Matejevu navodu te se može zaključiti da su oba autora bila u kontaktu s tekstom u Septuaginti (Gnilka, 1988, 476).

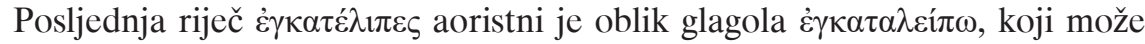
značiti “napustiti” (2 Kor 4,9), “ostaviti” (Mt 27,46; Mk 15,34), "zanemariti, propuštati” (Heb 10,25). U Markovu i Matejevu evanđelju dolazi jedino na tom mjestu. Taj glagol nema aktivno značenje, nego označava pasivnost, u smislu "ne biti nazočan u trenutku nevolje" (Popović, 2009, 291).

Zaključno možemo reći da gotovo svi egzegeti uzimaju za činjenicu da je trenutak Isusova krika pokazao svijetu ne samo njegov smrtni osjećaj težine i

3 Prema Barclayu $(1972,409)$ rimski vojnici mogli su pomisliti kako Isus zaziva Boga Helija zbog poganskoga običaja uzvikivanja suncu u velikoj nevolji. 
osamljenosti, nego stvarnu unutarnju napuštenost Sina od svojega Oca. Takav egzegetski zaključak nužno povlači veoma ozbiljna pitanja za kršćanski trinitarni nauk, prema kojem je Bog jedinstveno zajedništvo najveće i savršene ljubavi Oca i Sina i Duha Svetoga. Što se stvarno događa s božanskim Trojstvom u Isusovoj smrtnoj agoniji? Je li Isusova smrt, proživljena kao radikalna ostavljenost od Oca, istodobno i raspad, uništenje trojstvenoga zajedništva?

Tim se pitanjima ozbiljno bavila trinitarna teologija druge polovice 20. stoljeća, tražeći u unutartrojstvenim odnosima istodobno i rješenja nekih otvorenih pitanja suvremene antropologije. Osobito su zanimljiva promišljanja katoličkoga teologa Hansa Ursa von Balthasara i evangeličkoga teologa Jürgena Moltmanna.

\section{Otajstvo Isusove ostavljenosti u trinitarnoj teologiji Jürgena Moltmanna i Hansa Ursa von Balthasara}

Prema sudu nekih autora Jürgen Moltmann svojim je intenzivnim teološkim radom, koji je ostavio dubok trag u zapadnoj kršćanskoj teologiji druge polovice 20. i početka 21. stoljeća, postao jedan od najvažnijih kršćanskih autora svojega vremena (Gibellini, 1999, 279-296), a tako i Hans Urs von Balthasar, švicarski filozof i teolog, svojim je duhovnim promišljanjima ostavio dubok trag na cijeli kršćanski svijet (Gibellini, 1999, 238-254).

U ovom radu predstavljamo njihova promišljanja nad otajstvom križa, koji je za obojicu predstavljao i izuzetno važno polazište trinitarnoga nauka. Balthasar je rekao: »Drama između Boga i svijeta, koja kulminira u križu, može se dosljedno tumačiti [...] samo ako tu povijesnu dramu spasenja uspostavimo kao dramu koja se događa unutar Trojstva « (O’Donell, 1989, 270). Moltmann jednostavno zahtijeva da se Krist koji visi na križu razumije kao trojstveno raspeti Bog, što iziskuje da se o tom događaju govori samo i isključivo trinitarno (Moltmann, 2005, 233).

Isusovu vapaju ostavljenosti oba teologa pridaju stvarno povijesno značenje. Za Balthasara Isusov je vapaj »na jedinstvenost Isusovu sročena riječ, a nikako početak psalmodijske recitacije « (Balthasar, 1993, 99), osnovna riječ s križa koja ima primat vjerodostojnosti nad ostalima (Balthasar, 1993, 101). Moltmann, uspoređujući trenutak Isusove smrti kod svih evanđelista, odlučuje »pretpostaviti da je Markov teški način čitanja [Psalma 22,2] najbliži historijskoj zbilji« (Moltmann, 2005, 170). ${ }^{4}$

\subsection{Polazišta trinitarne teologije Jürgena Moltmanna}

Moltmann u same temelje svoje trinitarne teologije stavlja križ Kristov. Za njega Trojstvo nije samo jedan u povijesti očitovan oblik imanentne Božje biti,

4 Za otkrivanje trinitarno-kristoloških promišljanja dvojice autora koristimo se uglavnom njihovim tekstovima iz knjiga Raspeti Bog te Mysterium paschale i Samo je ljubav vjerodostojna, jer je u tim djelima na iscrpan način sadržan njihov nauk o smrti Boga na križu. 
jer između ekonomijskoga i imanentnoga Trojstva stoji uzajamnost u djelovanju koja čini da trojstveno oblikovana povijest spasenja, uključujući i muku, pripada Božjoj biti. Izraz te Božje biti i tajne Trojstva najzorniji je u događaju Kristove smrti. U Isusovu križu prepoznaje Moltmann teološki proces između Isusa i njegova Oca, proces kojim na križu napušteni Sin završava uskrsnućem u slavi Oca. »Križ Sina dijeli Boga od Boga sve do potpunog neprijateljstva i podjele. Uskrsnuće bogoostavljenog Sina povezuje Boga s Bogom u najintimnije zajedništvo« (Moltmann, 2005, 176). Ipak se Moltmann i prije razmišljanja o uskrsnuću želi suočiti s teologijom križa i Isusovim smrtnim vapajem kao sadržajem koji bitno određuje govor o Božjem biću. Prema njegovu mišljenju, istinska kršćanska teologija kao izričaj o Bogu mora biti i odgovor na pitanje o svakoj bogonapuštenosti jer se mora suočiti sa svim vapajima za Bogom u patnjama svih vremena. U kontekstu uskrsnuća ipak se u promišljanjima o Bogu treba vratiti na Isusovu napuštenost od Boga i iz nje promišljati unutarbožansko jedinstvo (Moltmann, 2005, 176-178). Time Moltmann želi pokazati Boga kao onoga koji je uronjen u povijest svijeta i ljudske sudbine, do koje mu je s ljubavlju stalo, pa u takvim nastojanjima zna ponekad otići i predaleko. »Sa svojim trojstvenim naukom Moltmann želi svu besmislenu i očajnu bol ovoga svijeta skriti u Boga« (Courth, 1999, 201).

\subsection{Moltmannova promišljanja o Isusovoj smrti}

U promišljanju Trojstva polazi Moltmann od otajstva križa. Čini mu se da je kasnija kršćanska tradicija ignorirala Isusovu unutarnju muku stavljajući naglasak na onu vanjsku. On naprotiv tvrdi da samo kroz razumijevanje unutarnje dinamike patnje kršćanska teologija može biti sposobna shvatiti što se je zaista dogodilo u Jeruzalemu na Golgoti. To on pokušava u svojem djelu Raspeti Bog. »Kako ćemo govoriti o Bogu, ovisi o tome koliko nam ozbiljno u uhu odzvanja Kristov vapaj na samrti: 'Bože moj, zašto si me ostavio?'« (Moltmann, 2007, 39).

Polazišna točka trojstvenoga promišljanja mu je stoga Isus »koji je umro sa znamenjem i izrazima duboke napuštenosti od Boga (Moltmann, 2005, 170). Kristovu smrt gleda u odnosu na Oca, pronalazeći u tom teološku dimenziju umiranja. To ga je pitanje zaokupljalo do te mjere da je prožimalo njegovu cjelokupnu teologiju, »biti upravo njezino središte i najsnažniji pokretač« (Pehar, 2011, 435). Reći će: »ili je od Boga napušteni Isus kraj svake teologije, ili je on početak jedne specifično kršćanske i u tome kritičke i oslobađajuće teologije i egzistencije« (Moltmann, 2005, 12). Događaj Isusove napuštenosti ne može zato prema njegovu zaključku biti tek recitacija psalma koja želi potvrditi Isusov trijumfalni završetak, nego duboko proživljena ostavljenost koja je pogodila cijeloga Isusa. On je ustrajno naviještao Boga, s kojim je imao izravnu vezu i mimo Mojsija i Zakona, što je u konačnici očitovano u oslovljavanju intimnim “Oče”. Stoga je osobito teško shvatljiva njegova napuštenost od takvoga Oca (Moltmann, 2005, 171).

Na križu Sin Očev više nema uvjerenje o Očevoj prisutnosti, štoviše, upućuje mu vapaj o razlogu ostavljanja. Moltmann to razumijeva kao tešku unutarnju muku. »Paklena muka jest biti s potpunom sviješću o milosrdnoj Božjoj blizini napušten od Boga i biti izručen smrti odbačenoga «(Moltmann, 2005, 171). Stoga 
u svojem promišljanju o Bogu kreće od Isusova vapaja na križu, koji označava napuštenost od Boga. Ta se napuštenost može razumjeti jedino trinitarno kroz odnos između Oca i Sina.

\subsection{Moltmannov trinitarni nauk $i$ Kristova ostavljenost na križu}

Moltmann postavlja pitanje o nužnosti povezanosti križa i Božjega unutartrojstvenoga života te odmah potvrdno odgovara na nj. Kršćanski nauk o Trojstvu mora započeti događanjem na križu »jer se u suprotnom slučaju na križu raskida jedinstvo Boga « (Moltmann, 2005, 396). Takvo polazište predstavlja za nj misao vodilju u tumačenju tajne imanentnoga Trojstva i djelovanja, koje on izjednačava s onim ekonomijskim (Moltmann, 2005, 396-398). Stoga ističe da je »nauk o Trojstvu kratka verzija pripovijesti o Kristovoj patnji u njezinu značenju za eshatološku slobodu vjere i života potištene naravi, a sadržaj nauka o Trojstvu jest sam realni Kristov križ« (Moltmann, 2005, 281). Nečuveni izraz da Bog ikoga ostavlja, a kamoli svojega Sina u najvećoj njegovoj boli, toliko je sablasna da ga ne iznenađuje kako je ta ideja s vremenom iščeznula iz teoloških spekulacija. »Stav da Bog napušta svojeg Sina ulazi među najnečuvenije iskaze Novog zavjeta. [...] Kako bismo krajnje oštro izrazili tu misao, mogli bismo riječima starozavjetne dogmatike kazati: prva osoba Trojstva ogrješuje se o drugu i uništava je... Ovdje do riječi dolazi theologia crucis kakva radikalnijom ne može biti« (Moltmann, 2005, 276-277).

Kada odgovara na pitanje mogućnosti takvoga jednoga čina, Moltmann odgovara polazeći iz perspektive Boga. Božje uzimanje napuštenosti i smrtnosti na sebe ne gleda kao uzimanje nečega što je jače od njega samoga, nego kao nešto što Bog svojim bitkom može nadići. »Križ stoji usred trojstvenog bitka Božjega [...] Onaj tko zbiljski kaže Trojstvo, taj zbilja govori o Isusovu križu i ne spekulira u nebeskim zagonetkama « (Moltmann, 2005, 232; Moltmann, 1980, 99). Kako bi se takav obrat shvatio, za Moltmanna je potrebno najprije odustati od slike svemoćnoga dalekoga Boga i Bogu dopustiti mogućnost patnje. Bog koji ne može patiti ne bi mogao ni voljeti, a Bog koji ne bi mogao voljeti ne može biti Bog. Bog je sasvim drukčiji od svih ljudskih predodžaba o njemu. »Bog nije bio čovjek po mjerilu naših predodžbi o čovječnosti. On je bio čovjek kakvog mi ne želimo, Odbačeni, Prokleti i Raspeti« (Moltmann, 2005, 236). Tako Moltmann u vapaju napuštenosti Sina na križu zaista prepoznaje rastavljanje Boga od Boga, dakle, svojevrsno slamanje unutartrojstvenoga života (Moltmann, 1980, 96-97), što je upravo ona najveća patnja kojom Bog na sebe preuzima patnju svijeta.

Upravo tim uzimanjem patnje svijeta u sebe i stavljajući je između sebe i svojega Sina Bog je pridružio sebi čovjeka i njegovu patnju i otvorio čovjeku put Bogu. »Samo kroz križ Kristov imamo pristup Bogu, Ocu« (Moltmann, 2005, 202). Na drugom govori: »Smrt Sina nije smrt Boga, već početak onog događanja Boga u kojem iz smrti Sina i boli Oca proizlazi oživljavajući Duh ljubavi« (Moltmann, 2005, 289). Tako se Božje biće otkriva kao ljubav za čovjeka. 


\subsection{Balthasarov pogled na tajnu Trojstva}

Slično kao Moltmann, i Balthasar je uvjeren da se promišljanja o Bogu nužno dotiču promišljanja o čovjeku i obratno. Tako se za njega iz pogleda upravljenoga na čovjeka otvara i pravi pristup nutarnjemu Božjemu bitku, koji je Trojstvo (Balthasar, 2005, 33-51). Najveća i definitivna manifestacija unutartrojstvene ljubavi ostvarena je u Kristovoj kenozi u liku Raspetoga na križu.

Kada se križ Kristov podrazumijeva kao objava Očeve ljubavi u Isusovoj smrti, što za posljedicu ima izlijevanje Duha Svetoga u srca ljudi, tada se prema Balthasaru uočava djelovanje Trojstva u svijetu. Na prijestolju križa Bog time što postaje savršeno drugi biva najbliži čovjeku te mu kroz formu Krista daje uzor za život. U samom razapinjanju, napose u njegovu vrhuncu - trenutku Isusove ostavljenosti — događa se završna kenoza, čija je posljedica okupljanje čovječanstva. Prema Balthasaru taj se čin može shvatiti isključivo trinitarno, a njime čovjek dobiva garanciju da neće umrijeti u ostavljenosti od Boga jer pred njim sada ima trajnoga zastupnika. Takvim izlaganjem Balthasar opisuje Boga koji beskrajno ljubi, a taj Bog »jest Raspeti, koji također može obuhvatiti moj križ i križeve sviju « (Courth, 1999, 198-199). Tako se otvara put djelovanja ekonomijskoga Trojstva u vremenu.

\subsection{Mučna ostavljenost Sina Božjega}

Kada tumači redak »Bože moj, Božje moj, zašto si me ostavio«, Balthasar počinje od Isusove molitve na Maslinskoj gori. Uoči muke Isus se povlači na goru, gdje doživljava svoje strahovanje u gorućoj molitvi Ocu za otklanjanjem onoga što predstoji. Što se je događalo u samoj osobi Isusa usred te samoće i straha, pitanje je na koje je ključno dati odgovor. Balthasar u redcima Mk 15,34 i Mt 27,46 pokušava uočiti Očevo predanje Sina i Sinovljevu poslušnost Ocu, koji su imanentno-trojstveno utemeljenje ekonomijski pokazane napuštenosti Isusa na križu, koja je počela još u Maslinskom vrtu. »Osamljenost, odlučujuća jedinstvenost toga trpljenja zaprečuje svaki pristup unutrašnjem doživljaju. Pa ipak, u toj nutarnjosti za kršćansku se vjeru krije cijeli spas svijeta« (Balthasar, 1993, 53). Vrhunac ostavljenosti od svih, pa i od samoga Oca, vidljiv je u smrtnom kriku i zovu s križa. Stoga se prema Balthasaru može uočiti stupnjevitost Isusova ostavljanja. Prva je ostavljenost ona od učenika koji su ga napustili, zatim od naroda koji ga se je odrekao, pa na kraju i od onoga s kojim je vezan u unutartrojstvenoj ljubavi (Balthasar, 1993, 55).

Nakon sve proživljene Isusove muke dolazi događaj križa, čiji je vrhunac smrtni krik ostavljenosti. I prema Balthasaru pogrešno je taj evanđeoski redak gledati kao običnu recitaciju psalma, ili pak kao posljednju propovijed upućenu židovima. Ostavljenost je događaj, činjenica koja je potpuno pogodila Isusovu osobu. »Radi se o tome da Isus do kraja pretrpi protubožansku silu, i to u Duhu, što nije nikako neka psihološka datost, nego ista stvarnost u kojoj se, prema Iv 4,23 klanja Ocu. Trpljenje dolazi napokon od Oca i biva prihvaćeno« (Balthasar, 1993, 98). 
Taj se događaj s jedne strane može shvatiti kao primjer svima koji ga žele nasljedovati, a s druge strane i kao mogući odgovor na teodicejsko pitanje, jer se u njemu Isus solidarizirao sa svima koji su sami. »Solidarnost ovdje znači: S drugima biti osamljen«(Balthasar, 1993, 136). No i Balthasar je svjestan da cijeli taj istiniti proces, koji je duboko pogodio čovjeka Isusa, tek kada se tumači iz uskrsne perspektive, može pomoći vjerniku da dublje pronikne u otajstvo Boga, kojega je Krist objavio (Balthasar, 1993, 157). I zato Balthasar sve navedeno uzima kao podlogu poniranja u tajnu imanentnoga Trojstva, koje se u događaju Kristove napuštenosti objavilo u punom sjaju svoje vjerodostojne ljubavi.

\subsection{Unutarnja Božja ostavljenost}

Razmišljanje o Kristovu križu za Balthasara proizlazi iz vjere da je na tom križu umro Sin Božji. Jedini put shvaćanja mudrosti skrivene u otajstvu (usp. 1 Kor 2,7) proizlazi iz »dublje šutnje i tamnijeg ponora negoli ga obična filozofija može poznavati«(Balthasar, 1993, 48). Najdublju šutnju Balthasar vidi u osamljenosti Krista na križu koja je prethodila njegovu umiranju. No, pita se kako povezati mrtvoga Bogočovjeka s objavljenim Bogom. Kako je moguće da Sin nerazdruživo združen s Ocem zavapi: »Bože moj, Bože moj, zašto si me ostavio? « Jedini je smisleni način za Balthasara shvatiti Kristovu osamljenost kao događaj koji se odvija u tajni unutartrojstvenoga odnosa Oca i Sina, »budući da svaka situacija u vezi sa spasenjem u životu, smrti i uskrsnuću Isusa Krista u krajnjoj liniji može biti tumačena samo trinitarno« (Balthasar, 1993, 137; usp. Krenski, 1990, 95-126).

U događajima muke on prepoznaje Očevo predanje Sina, s čime je Sin suglasan, iako to nije bila njegova volja. Bog ne može ignorirati grijeh i stoga ga želi upustiti u prostor svoje ljubavi kako bi kao janje Božje uzeo grijeh svijeta na sebe (Balthasar, 1999, 67). Stoga se u vapaju osamljenika i u Isusovoj ostavljenosti iščitava Božja ljubav. Iz smjera Oca prema Sinu izražava se kao predanje, iz smjera Sina prema Ocu kao poslušnost, a iz smjera Boga prema ljudima kao Duh, koji je iz njihove ljubavi došao na svijet. Na taj način ljubav Božja biva i ostaje vjerodostojna. »Izručen kao 'taj čovjek tu' postavljen je na svjetsku pozornicu, a unutar scene Ecce homo skriva se Ecce Deus. To je sada jedina valjana i obvezujuća slika onoga što je grijeh svijeta: za Božje srce vidljiv 'na tom čovjeku' « (Balthasar, 1993, 94).

$\mathrm{Na}$ taj način Isus pobjeđuje ljudsku vremenitu smrt, ali i onu vječnu, koja je posljedica grijeha. »Isus ne nosi samo sudbinu Adamovu, već izričito grijehe ljudskog roda, a time i drugu smrt napuštenosti od Boga (Balthasar, 1993, 68). Od trenutka kada je Isus postao grijehom za nas (usp. Gal 3,13) kako bi pomirio čovjeka s Bogom, Otac se udaljio od njega. »On je došao da [...] trijumfira nad silama i moćima. No taj se trijumf odigrava u kriku napuštenosti od Boga [...] To je pad prokletnika što dalje od Boga, pad poosobljenog grijeha « (Balthasar, 1993, 35).

Iz Isusove ostavljenosti Balthasar uočava kako on nosi grijeh svijeta kao jedino što je Božja negacija i na taj način djelom ljubavi izmiruje svijet s Bogom (Balthasar, 1993, 88). Kristov je odgovor na predanje kenotička poslušnost (Balthasar, 
1993, 67-69). Ona je Kristova slobodna volja i iskaz kenotičke sinovske ljubavi prema Ocu (Balthasar, 1993, 69). Dragovoljno prihvaća biti grijehom za nas i kao takav je od svojega Oca potpuno ostavljen, da bi ta ostavljenost na križu mogla biti »medij pomirenja između Oca i nas, koji smo njegova djeca po Duhu koji u nama stanuje « (Balthasar, 1993, 113).

Iz svega se vidi da su redci o Isusovoj ostavljenosti na križu Mk 15,34 i Mt 27,46, kada ih se koristi kao trinitarni iskaz, za Balthasara vjerodostojan prikaz Kristove napuštenosti od Oca, ostavljenosti po kojoj čovjek može dublje proniknuti u tajnu Trojstva. Ta je ostavljenost u Isusovoj smrti bila nužna kako bi se pobijedio grijeh svijeta, a u njegovu je uskrsnuću bila nadiđena. Posljedica je toga ulazak čovjeka u božanski život i izlijevanje Duha na svijet.

\section{Mjesto i uloga Duha Svetoga u Trojstvu i svijetu}

I prema Moltmannu i prema Balthasaru jasno je da se u smrtnom razdvajanju Oca i Sina mora postaviti i pitanje uloge Duha Svetoga. Iako Moltmann i sam priznaje da u njegovoj teologiji križa nije dostatno istaknuta osobnost Duha Svetoga, koja do punoga izraza dolazi tek u izlaganju teologije proslavljenja (Moltmann, 2005, 402; Moltmann, 1980, 137-143 i 194-203), on je kasnije isticao misao o predanju, prema kojoj Otac predaje Sina, Sin se predaje Ocu, a to se pre-

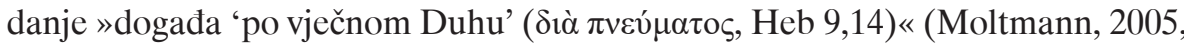
403). Na tragu Augustinova trinitarnoga nauka on unutartrojstvenu ulogu Duha definira kao vinculum amoris, savez ljubavi, koji »razdvojenost i jedinstvo Oca i Sina sjedinjuje u smrti na križu « (Moltmann, 2005, 403-404; usp. Moltmann, 1980, 98). Dakle, Duha Svetoga u Kristovoj smrtnoj napuštenosti treba gledati kao onoga koji tu napuštenost, razdvojenost Oca i Sina, premošćuje i ponovno ih spaja u jedinstvo.

Kod Balthasara Duh je onaj koji je prisutan unutar Kristove napuštenosti, ali prema ljudima postaje očit tek u događaju nadvladavanja udaljenosti prve i druge božanske osobe. »Sjedinjenje Oca i Sina, koji je otišao u svijet i na križ te potpuno ispunio poslanje, pretpostavka je ekonomijskom izlaženju Duha u Crkvu i u otkupljeni svijet «(Balthasar, 1993, 179-180). Dakle, i prema Balthasaru i prema Moltmannu ostavljenost Krista na križu bila je unutarnji uvjet mogućnosti njegove smrti, a samim time i očitovanja Duha, koji je bio u tom trenutku prisutan (Moltmann), ali za ljude vidljiv tek nakon što se je Sin opet sjedinio s Ocem (Balthasar). Duh, koji premošćuje ponor između Oca i Sina (Balthasar, 1993, 35-36), u unutartrojstveni život uvlači čovjeka. No gledajući i s druge strane, ne samo da čovjek ulazi u unutartrojstveni život po izlijevanju Duha, nego po nadilaženju napuštenosti Sina od Oca prima u srce živu ljubav između njih dvojice (Balthasar, 1993, 116). Otvaranjem toga unutartrojstvenoga "mjesta" za čovjeka stvara se dogmatska podloga teološkoga pristupa čovjeku u njegovoj cjelovitosti kroz psihološku, socijalnu i političku dimenziju. Moltmann je rekao: »Kada kršćanska vjera misli trojstveno, ona tada kaže da su napušteni ljudi s Kristovom napuštenošću već uključeni u božansku povijest i da živimo u Bogu zato što sna- 
gom Kristove smrti stječemo udio u Božjem eshatološkom životu « (Moltmann, 2005, 293).

Kao onaj koji živi po Duhu u eshatološkom Božjem životu, čovjek i zakone po kojima sada živi unosi po Kristovoj muci i smrti u samog Boga, ali ne na način da bi tako Boga izmijenio, nego da bi tako trojstveni Bog po svojoj ljubavi mogao nadvladati i razriješiti spone koje vežu čovjeka. To, dakako, ne treba shvatiti kao da bi trinitarna teologija površno predstavljala funkcionalizaciju problema čovjeka i svijeta, nego je riječ o soteriološkom ukazu na ekonomijske eksplikacije imanentnoga nauka o Bogu. A to je moguće samo trinitarnim promišljanjem Isusove napuštenosti na križu, dakle kroz puninu Božjega trojstvenoga života, obilježenu međusobnim djelovanjem Oca, Sina i Duha Svetoga. Otac je Bog koji ljubavlju predaje Sina, Sin je Bog koji predanjem života uzvraća ljubav Ocu za spas svijeta, Duh Sveti je ljubav koja povezuje Oca i Sina te u taj božanski život ljubavi uvlači čovjeka. Tako u Duhu Svetom čovjek svoj život i svoju smrtnost unosi u smrt Boga, a po Duhu Svetom i Bog dotiče čovjeka s ciljem njegova cjelovitoga oslobođenja.

S takvim trinitarnim naukom Moltmanna i Balthasara, u kojem iz napuštenosti i ponovnoga sjedinjenja Oca i Sina silazi na čovjeka Duh Sveti, koji ga pobožanstvenjuje i djeluje u njegovu srcu, kršćanska vjera može ući u dijalog sa svim partikularnim antropologijama i dičiti se kako ranjenoga čovjeka stavlja na najviše mjesto, na mjesto unutar samoga raspetoga Boga, gdje je došao po Kristovoj krajnjoj ostavljenosti.

\section{Zaključak}

Provedenom kritičkom egzegezom i teološkom analizom potvrđeno je da redci Mk 15,34 i Mt 27,46 svjedoče da se je Krist u svojem smrtnom času osjećao i stvarno bio napušten od Oca, te imaju egzegetski i teološki potencijal da u izlaganju trinitarnoga otajstva budu prepoznati i uvaženi kao temeljni trinitarno-teološki iskaz Novoga zavjeta. U Isusovu vapaju, a prema egzegezi možemo reći i ču-

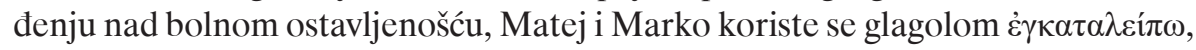
koji bez ublažavanja označava realnu ostavljenost Isusa od njegova Oca.

Balthasar i Moltmann, svaki unutar svojih teoloških promišljanja, iako s bitnim unutarnjim razlikama svojih teoloških doprinosa, uočili su da je taj bolni vapaj bio izraz stvarne i duboke potresenosti umirućega Isusa na križu. Iz naizgled začuđujuće činjenice da je u smrtnom času Otkupitelj svijeta pretrpio napuštenost od samoga Oca, ta dva teologa prepoznala su otvorena pitanja za klasični kršćanski nauk o Bogu kao savršenom zajedništvu, ali i mogućnost novoga tumačenja unutartrojstvenih odnosa i samoga Božjega bića. Obojica uočavaju kako se je na križu dogodila stvarna i bolna razdvojenost Sina od njegova Oca te je na taj način Sin radikalno i dosljedno dovršio proces očovječenja započet inkarnacijom, proces po kojem je do kraja preuzeo ljudskost da bi čovjeku u svoj radikalnosti i ozbiljnosti ponudio svoju božanstvenost. Naglašavaju kako je samo svojevrsnim kenotičkim "razaranjem" nutarnjega božanskoga zajedništva unutar Boga moglo 
ući i ono što nije božansko: sva čovjekova napuštenost, slabost i smrtnost, koju je Bog pobijedio uskrsnućem Isusa od mrtvih. Kao i utjelovljenje, tako se i Isusova osamljenost u smrti na križu pokazuje kao eksplikacija unutarbožanskoga razlikovanja Oca i Sina, ali i kao osobita mogućnost soteriološkoga razlaganja nauka o trojstvenom Bogu. Supatništvo Sina s čovjekom do najradikalnijega iskustva ostavljenosti i osamljenosti, pa i one koja je rez u samom Bogu, pokazuje Boga ljubav, koji kenozom u samom sebi stvara "mjesto" za čovjeka, te time promiče njegovo dostojanstvo i spašava ga. To stvaranje prostora za čovjeka unutar Boga djelo je Duha Svetoga, veze ljubavi između Oca i Sina i veze ljubavi Boga s čovjekom.

U teološkim doprinosima Balthasara i Moltmanna pokazuje se da Isusova realna razdvojenost od Oca u smrti ipak ne dovodi u pitanje kršćanski nauk o Trojstvu kao zajedništvu ljubavi. Razdvojenošću Oca i Sina na križu taj je nauk zapravo istinski rasvijetljen u soteriološkom značenju propter nos homines. Tako, na pitanje postavljeno u uvodu, je li od Oca napušteni Isus kraj trinitarne teologije, odnosno kršćanskoga nauka o Bogu, može se na kraju odgovoriti da se upravo u Isusovoj smrtnoj ostavljenosti pronalazi najsnažniji temelj soteriološki izložene trinitarne teologije, jer se trojstveno zajedništvo u Duhu Svetom potvrđuje kao zajedništvo ljubavi koja uključuje ne samo sebi jednakoga, nego i potpuno drugoga i drukčijega, koja se otvara i izvan samoga Boga i u Bogu stvara "mjesto" za čovjeka. A nije manje važno da i trinitarna teologija, temeljena na tom otajstvu, prestaje biti apstraktna spekulacija unutartrojstvenih odnosa, te postaje odgovor par exellance na egzistencijalna pitanja patnje i traganja čovjeka za spasenjem u svakom, pa i sadašnjem vremenu.

\section{Literatura}

Balthasar, Hans Urs von (1993). Mysterium paschale: Sveto trodnevlje smrti, pokopa i uskrsnuća našega Spasitelja. Zagreb: Kršćanska sadašnjost.

Balthasar, Hans Urs von (1999). Samo je ljubav vjerodostojna. Zagreb: K. Krešimir.

Barclay, William (1972). The Gospel of Matthew. Michigan: St. Andrew Pr.

Biblija. Sveto pismo Staroga i Novoga zavjeta. Prevoditelji: Silvije Grubišić (Petoknjižje), Filbert Grass (Psalmi), Nikola Miličević (Pjesma nad pjesmama), Antun Sović (ostali dijelovi Staroga zavjeta), Bonaventura Duda i Jerko Fućak (Novi zavjet). Imprimatur: Hrvatska biskupska konferencija, 10. listopada 2008. Zagreb: Kršćanska sadašnjost, 2015.

Brather, Robert G.; Nida, Eugene A. (1961). A translator's handbook on the Gospel of Mark. London: United Bible Societies.

Brown, Raymond E. (2008). Uvod u Novi zavjet. Zagreb: Kršćanska sadašnjost.

Courth, Franz (1999). Bog trojstvene ljubavi. Zagreb: Kršćanska sadašnjost.

Fabris, Rinaldo (1996). Matteo. Roma: Borla.

Focant, Camille (2015). Il vangelo secondo Marco. Assisi: Cittadella Editrice.

France, Richard T. (1987). Tumačenje Evanđelja po Mateju. Novi Sad: Dobra vest.

Gibellini, Rosino (1999). Teologija dvadesetog stoljeća. Zagreb: Kršćanska sadašnjost.

Gnilka, Joachim (1988). Das Matthäusevangelium II. Freiburg: Herber. 
Krenski, Thomas Rudolf (1990). Passio Caritatis: Trinitarische Passiologie im Werk Hans Urs von Balthasar. Freiburg: Johannes Verlag Einsiedeln.

Lane, William L (1974). The Gospel According to Mark: The English text with Introduction, Exposition, and Notes. Michigan: Grand Rapids.

Moltmann, Jürgen (1980). Trinität und Reich Gottes: Zur Gotteslehre. München: Gütersloher Verlagshaus.

Moltmann, Jürgen (2005). Raspeti Bog: Kristov križ kao temelj i kritika kršćanske teologije. Rijeka: Ex libris.

Moltmann, Jürgen (2007). Božja pasija. U: Zoran Grozdanov (ur.), Zbornik u čast Jürgena Moltmanna: Bog pred križem (str. 37-54). Rijeka: Ex libris.

Müller, Gerhard Ludwig (2005). Katholische Dogmatik: Für Studium und Praxis der Theologie. Freiburg: Herder.

Nestle, Eberhard; Aland, Kurt (ur.) (1986). Novum testamentum Graece et Latine. Stuttgart: Deutsche Bibelgesellschaft.

O’Donell, John (1989). Alles sein ist Liebe, Eine Skizze der Theologie Hans Urs von Balthasars. U: Karl Lehman i Walter Kasper (ur.), Hans Urs von Balthasar: Gestalt und Werk (str. 260-276). Köln: Communio.

Pehar, Marija (2011). Od nužnosti nemogućnosti do izbora ljubavi: Teodicejsko traganje kao pitanje Božjega bića na primjeru Moltmannova nauka o Bogu. Bogoslovska smotra, 81(2), 423-443.

Popović, Anto (2009). Isusova muka i smrt prema Markovu evanđelju. Zagreb: Kršćanska sadašnjost.

Popović, Anto (2016). Grčko-hrvatski rječnik Novoga zavjeta sa statistikom grčkih riječi. Zagreb: Kršćanska sadašnjost.

Rahlfs, Alfred (ur.) (1979). Septuaginta. Id est Vetus Testamentum graece iuxta LXX interpretes, Stuttgart: Deutsche Bibelgesellschaft.

Zovkić, Mato (1983). Isus patnik i čovjekova patnja u Novom zavjetu. Bogoslovska smotra, 53(4), 186-208. 
Jesus' Abandonment on the Cross and the Christian Understanding of God as a Trinitarian Communion

An exegetical and Trinitarian-theological analysis of Mk. 15:34 and Mt. 27:46 through the theology of J. Moltmann and H.U. von Balthasar

Marija Pehar*, Vjeran Lazć**

\section{Summary}

In this paper, we reflect on Jesus' revelation of God as the Trinitarian communion beginning with his abandonment and separation from his Father at the time of his death on the cross as expressed in his outcry: »My God, my God, why have you forsaken me? "(Mk. 15:34; Mt.27:46) The first part of the paper puts forth a historical-critical exegesis of the aforementioned lines of the New Testament in their Greek original, while reflecting on the question of whether Jesus' abandonment by his heavenly Father may be understood also as a significant critique of the Christian doctrine of God as being an indivisible communion of love. Hence in the second section, we confront the results of this analysis with the Christian Trinitarian doctrine, specifically by presenting the Trinitarian-theological contribution of Moltmann and Balthasar. In the third section, the paper points out the true Trinitarian and theological potential of Jesus' real abandonment in his death on the cross through the pneumatological dimension and soteriological orientation of the doctrine of the Trinity as a possible new interpretation of God as love.

Key words: Jesus' abandonment; Trinity; Jürgen Moltmann; Hans Urs von Balthasar

* Marija Pehar, Ph.D., Associate Professor, Catholic Faculty of Theology, University of Zagreb. Address: Vlaška 38, 10000 Zagreb, Croatia. E-mail:m.marijape@gmail.com

** Vjeran Lazić, Doctorand, Faculty of Humanities and Social Sciences, University of Zagreb. Address: Ivana Lučića 3, 1000 Zagreb, Croatia. E-mail: vjeran.09@gmail.com 